\title{
UJI ANTAGONIS Fusarium SP. PADA KANGKUNG BELERANG TERHADAP ISOLAT KITINOLITIK LT4 DARI LIMBAH CAIR TAHU
}

\author{
Jane Melita Keliat ${ }^{1)}$ danWinny Iftari ${ }^{2}$ ) \\ 1,2)Fakultas Pertanian, Universitas Nahdlatul Ulama Sumatera Utara, \\ Jln. H. Abdul Manaf Lubis No. 2 Gaperta Ujung, Tanjung Gusta Medan 20215 \\ Email : jane310189@gmail.com
}

\begin{abstract}
ABSTRAK
Uji antagonis Fusarium sp. pada tanaman kangkung belerang terhadap isolat kitinolitik LT4 telah dilakukan pada Bulan September 2017. Identifikasi dengan gen penyandi 16s rRNA menunjukkan isolat LT4 tergolong bakteri Bacillus subtilis. Zona hambat Bacillus sp pada hari ke- 6 sebesar 1,39 $\mathrm{cm}$. Pengamatan secara mikroskopis setelah dilakukan uji antagonis, Fusarium sp. mengalami keabnormalan hifa seperti hifa menggulung dan hifa lisis.
\end{abstract}

Kata kunci: Fusarium, Kitinolitik, Bacillus sp.

\section{THE ANTAGONISTIC TEST OF FUsarium sp. FROM SULFUR WATER KALE AGAINST LT4 CHITINOLITIC ISOLATE FROM LIQUID WASTE TOFU}

\begin{abstract}
The antagonistic test of Fusarium s. from sulfur water kale against LT2 chitinolitic isolate has been done on September 2017. Identification LT4 isolate using 16s rRNA showed Bacillus sp. Based on the antagonistic test, it was shown that Bacillus sp in inhibiting the growth of Fusarium sp with inhibition zone radius of $1,39 \mathrm{~cm}$ at sixth days. By microscopic of Fusarium sp. after the antagonistic test against Bacillus sp., abnormal hyphae of fusarium sp. in rolled and lysis.
\end{abstract}

Keywords: Fusarium, Chitinolitic, Bacillus sp.

\section{Pendahuluan}

Bakteri kitinolitik dalam mengendalikan jamur didasarkan kepada kemampuan mendegradasi dinding sel jamur. Kitinase menghidrolisis ikatan glikosidik $\beta-1,4$ senyawa kitin sehingga terbentuk oligomer kitin yang lebih sederhana dan lebih mudah dihidrolisis. Bakteri kitinolitik yang berasal dari tanah di beberapa daerah Sumatera Utara dan Bangka menunjukkan kemampuannya dalam menghambat $G$. boninensis, F. oxysporum, dan P. Citrinum (Suryanto et al. 2011). Bacillus sp. BK17 merupakan bakteri tanah yang berasal dari daerah Bangka yang telah diketahui berpotensi menghasilkan enzim kitinase yang menghambat pertumbuhan jamur patogen (Suryanto. 2008). Enzim kitinase dari Bacillus sp. BK17 mampu menghambat F.oxysporum penyebab layu Fusarium pada benih cabai merah (Suryanto, et. al., 2014). Enzim kitinase dari Bacillus sp. BK17 mampu menghambat G.boninenses penyebab busuk pangkal batang pada bibit tanaman kelapa sawit (Suryanto et. al., 2012). Enzim kitinase dari Bacillus sp. BK17 juga mampu menghambat
Sclerotium rolfsii rebah kecambah pada kedelai (Malinda, 2013).

Kitinase memiliki kemampuan mendegradasi limbah yang mengandung kitin (Hirano, 1996), dalam bidang pertanian kitinase berperan sebagai kontrol patogen tanaman (Dahiya et al. 2005). Hasil pengujian in vitro enzim kitinase ekstraselluler, Cellulosimicrobium cellulans 191 mampu melisiskan dinding sel jamur Rhizopus oligosporus, Mucor miehei, Penicillium sp., Streptomyces. phaerochromogenes, Trichoderma viride (Fleuri et al. 2009).

Kangkung belerang merupakan tanaman yang satu-satunya dibudidayakan di Desa Semangat Gunung Kabupaten Karo (www.karokab.go.id). Namun produksi kangkung belerang mengalami penurunan. Batang kangkung belerang menguning dan layu sering mengakibatkan gagal panen. Hal ini diduga disebabkan oleh jamur Fusarium. Untuk itu, perlu dilakukan upaya mengisolasi dan menguji pertumbuhan Fusarium pada tanaman kangkung belerang terhadap isolate kitinolitik LT2. 


\section{Bahan dan Metode Alat dan Bahan}

Alat dan bahan yang digunakan meliputi cawan petri, botol kaca, Laminar Air Flow (LAF), pipet tetes, pipet serologi, inkubator termofil, objek glass, cover glass, ose bengkok, hockey stick, magnetic stirer, hotplate, stirer, Erlenmeyer 500 $\mathrm{mL}$, Beaker glass500 $\mathrm{mL}$, tabung reaksi, gelas ukur $500 \mathrm{ml}$, mikroskop, sampel limbah cair tahu, Medium Garam dalam $1000 m L\left(\mathrm{KH}_{2} \mathrm{PO}_{4} 0,14 \%\right.$, $\mathrm{K}_{2} \mathrm{HPO}_{4} 0,06 \%, \quad \mathrm{MgSO}_{4} \cdot 7 \mathrm{H}_{2} \mathrm{O} \quad 0,1 \%, \quad \mathrm{FeSO}_{4} \cdot 7 \mathrm{H}_{2} \mathrm{O}$ $0,02 \%, \mathrm{ZnSO}_{4} 0,002 \%, \mathrm{MnCl}_{2} 0,002 \%$ ), koloidal kitin 0,3\%, agar-agar, akuades, alkohol 70\%, spirtus, blankdisc, yeast ekstrak 0,1\%, Nutrient Agar, Malacheet Green, iodine, dan safranin.

\section{Metode Kerja}

Isolasi Jamur Fusarium. Isolat jamur Fusarium sp. dilakukan dengan isolasi langsung dari tanaman kangkung belerang.

Identifikasi Isolat LT2. Isolat LT2 merupakan isolat yang diperoleh dari limbah cair tahu. Isolat LT2 diidentifikasi dengan menggunakan gen penyandi 16 s rRNA.

Uji Antagonis Fusarium pada Tanaman Kangkung Belerang dengan Bakteri Kitinolitik isolat LT2. Aktivitas penghambatan ditentukan berdasarkan zona hambat yang terbentuk di sekitar koloni. Pengamatan dimulai dari hari ke- 6 sampai hari ke-10. Pengukuran pertumbuhan fungi patogen dilakukan dengan cara mengukur batas akhir pertumbuhan dari fungi patogen (Martorejo, 2001).

\section{Hasil dan Pembahasan \\ Isolasi Jamur Fusarium dari Tanaman Kangkung Belerang.}

Isolasi jamur Fusarium dilakukan terhadap tanaman kangkung belerang yang terserang penyakit. Pada tanaman kangkung belerang yang terserang penyakit, gejala yang ditimbulkan adalah batang yang berwarna kuning menjadi coklat dan keriput dan bagian daun berwarna kuning hingga coklat sehingga dapat menyebabkan tanaman kangkung belerang menjadi layu dan mati.

Hasil isolasi dari bagian batang tanaman kangkung belerang menunjukkan patogen tersebut adalah Fusarium yang memiliki miselium berwarna putih. pada media Sabarouth Dextrose Agar (SDA) dan media Potato Dextrose Agar (PDA) disekitar koloni jamur berubah menjadi warna kuning (Gambar 1.)

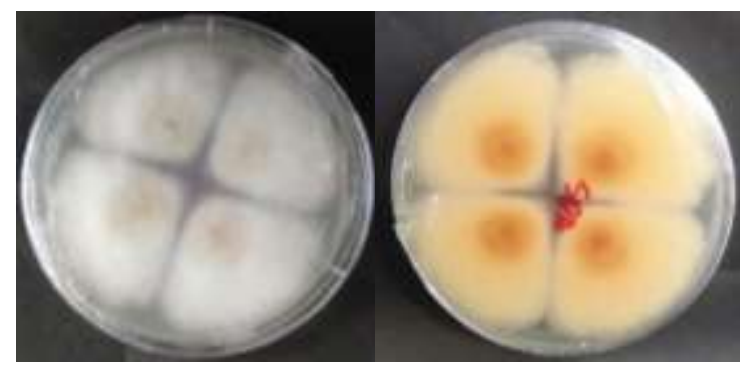

Gambar 1. Isolat jamur Fusarium sp. pada Media PDA dan SDA

Pada pengamatan mikroskopis memperlihatkan konidia berbentuk lonjong, mikrokonidia hialin dan lonjong, makrokonidia hialin berbentuk sabit, bertangkai kecil dan bersekat (Gambar 2.)

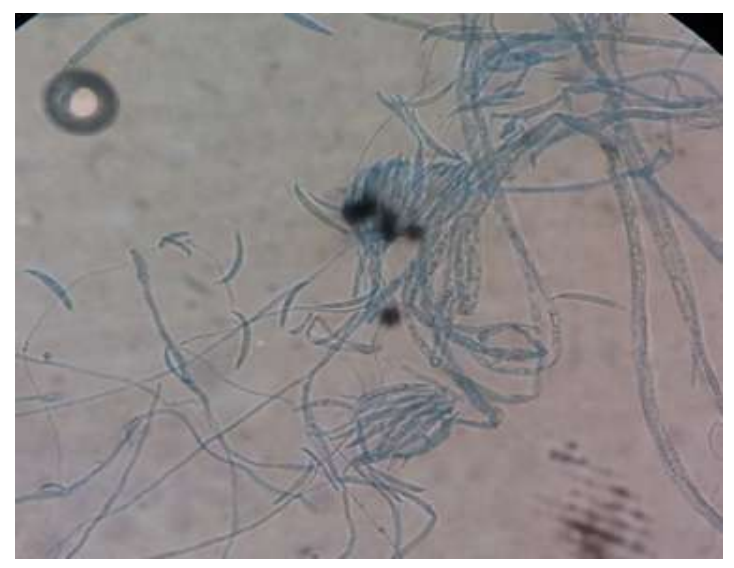

Gambar 2. Pengamatan Mikroskopis Perbesaran 65x10. Jamur Fusarium sp. Pada Tanaman kangkung Belerang

Pada penelitian yang dilakukan oleh Suryani et al., 2013 bahwa koloni Fusarium oxysporum isolat A memiliki warna putih pucat kekuningan dengan spora berwarna putih. Sementara itu, koloni Fusarium oxysporum isolat B berwarna keunguan (violet) dengan warna spora putih. Secara mikroskopis, kedua spesies Fusarium oxysporum ini memiliki lebih banyak persamaan hanya saja pada jumlah makrokonidia dan bentuk mikrokonidia terdapat sedikit perbedaan.

Menurut Murad et al., (2016) bahwa keutamaan Fusarium oxysparum terletak pada makrokonidia yang berbentuk panjang dan pendek menengah, berdiding tebal dan melengkung. Mikrokonidia berbentuk oval. Karakteristik lain berwarna putih sampai ungu pucat dari banyaknya miselium yang berwarna putih. Klamidospora berbentuk oval yang terbentuk secara tunggal dan berpasangan. 


\begin{abstract}
Identifikasi Isolat Terpilih dengan menggunakan gen penyandi 16s rRNA

Dari hasil identifikasi berdasarkan gen penyandi $16 \mathrm{~S}$ rRNA dengan menggunakan primer 63s (5'-CAG GCC TAA CAC ATG CAA GTC-3') dan 187r (5'-GGG CGG WGT GTA CAA GGC-3') menunjukkan bahwa isolat LT4 tergolong ke dalam Bacillus sp. Bakteri ini tergolong ke dalam bakteri gram positif berbentuk batang.
\end{abstract}

\section{Uji Antagonis Fusarium pada Tanaman Kangkung Belerang dengan Bakteri Kitinolitik Isolat LT2.}

Hasil uji antagonisme Fusarium kangkung belerang menunjukkan bahwa Bacillus sp. mampu menghambat pertumbuhan fungi patogen. Adapun zona hambatan dapat dilihat pada Tabel 1.

Tabel 1. Zona Hambat Fusarium sp. terhadap Bacillus sp.

\begin{tabular}{ccc}
\hline No & Hari ke- & Zona Hambat $(\mathbf{c m})$ \\
\hline $\mathbf{1}$ & 1 & 0,11 \\
$\mathbf{2}$ & 2 & 0,42 \\
$\mathbf{3}$ & 3 & 0,65 \\
$\mathbf{4}$ & 4 & 0,93 \\
$\mathbf{5}$ & 5 & 1,28 \\
$\mathbf{6}$ & 6 & 1,39 \\
\hline
\end{tabular}

Dari hasil pengamatan dapat dilihat bahwa terjadi peningkatan besar zona hambat sampai hari ke-6 yakni 1,39 cm. Penghambatan pertumbuhan jamur ditandai dengan adanya zona hambat di sekitar daerah tumbuhnya hifa jamur yang menunjukkan adanya aktivitas hidrolisis oleh kitinase terhadap dinding sel jamur.

Bakteri kitinolitik memiliki kemampuan yang berbeda dalam menghambat pertumbuhan patogen tanaman. Penelitian yang dilakukan oleh Malinda (2013), isolat BK13 menunjukkan penghambatan sebesar $3,75 \mathrm{~cm}$, isolat BK15 sebesar 3,70 cm; sedangkan isolat BK17, KR05, LK08, PB017 tidak menunjukkan adanya penghambatan terhadap Sclerotium rolfsii.

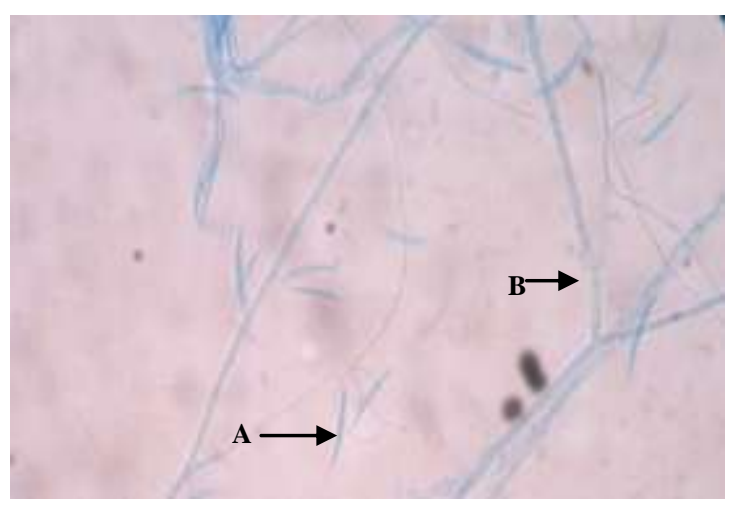

Gambar 2. Hifa abnormal Fusarium sp. A. Hifa Menggulung; B. Hifa Lisis. Perbesaran 65x10
Pengamatan secara mikroskopis dari uji antagonis yang dilakukan dengan menggunakan Fusarium dari tanaman kangkung belerang terhadap Bacillus $s p$. dari limbah cair tahu menunjukkan hifa abnormal seperti, menggulung dan lisis. Menurut Suryanto (2010) menunjukkan bahwa hasil uji antagonis Fusarium terhadap isolat kitinolitik lokal meliputi, melilit, keriting dan lisis; menggulung-gulung, lisis dan menyatu. Beberapa isolat bakteri kitinolitik berpotensi untuk dikembangkan sebagai agen pengendali hayati patogen tanaman.

\section{Ucapan Terimakasih}

Ucapan terimakasih kami ucapkan kepada KEMENRISTEKDIKTI yang telah memberikan Hibah Penelitian Dosen Pemula Tahun 2017.

\section{Daftar Pustaka}

Dahiya, N., Tewari, R., Tiwari, P. \& Hoondal, G. S. 2005. Production of an antifungal chitinase from Enterobacter sp. NRG4 and its application in protoplast production. World J. Microbiol. Biotechnol. 21: 16111616.

Fleuri, L. F., Kawaguti, Y. H. \& Sato, H. H. 2009. Production, purification and application of extracellular chitinase from Cellulosimicrobium cellulans 191. Braz. J. Microbiol. 40: (3). 623-630.

Hirano, S. 1996. Chitin biotechnology applications. Biotechnol. Annu. Rev. 2: $237-258$.

Kabupaten Karo. 2016. http:www.karokab.go.id. Diakses Bulan Maret 2016.

Malinda, N. Suryanto, D. dan Nurtjahja, K. 2013. Penghambatan Serangan Sclerotium rolfsii Penyebab rebah Kecambah pada Kedelai Dengan Bakteri Kitinolitik, Skripsi. Departemen Biologi, Universitas Sumatera Utara.

Martorejo, T., C., Sumardiyono., dan Astuti, E.H. 2001. Kajian Pengendalian Hayati Kapang Hijau pada Buah Jeruk dengan Trichoderma sp. Prosiding Seminar PFI. IPB. Bogor. 354-356.

Murad, N. B. A., Kusai, N. A., dan Zainudin, N. A. I. M. 2016. Identification and diversity of Fusarium species isolated from tomato fruits. Journal of Plant Protection Research. $56(3)$.

Suryani, I.A., Ramona, Y., dan Proborini, M. W. 2013. Isolasi dan Identifikasi Jamur Penyebab Penyakit Layu dan Antagonisnya Pada Tanaman Kentang yang Dibudidayakan Di Bedugul, Bali. Jurnal Biologi. 17(2):37.

Suryanto, D. 2008. Potensi pemanfaatan isolat kitinolitik lokal untuk pengedalian hayati 
jamur. Prosiding Seminar Hasil-hasil Penelitian, Unversitas Sumatera Utara.

Suryanto, D., Asnita, N., Sihombing, S., Maimunah, S., \& Nurtjahja, K. 2010. Penghambatan pertumbuhan jamur dari tiga tanaman ekonomi Sumatera Utara oleh bakteri kitinolitik. Seminar Nasional Biologi. Medan: Fakultas MIPA. Universitas Sumatera Utara.

Suryanto, D., Asril, M., Munir, E., Kardhinata, H.E. 2014. Assay of Antagonistic Bacteria of Single Isolate and Combination to Control Seedling-off in Chili Seed caused by Fusarium oxysporum. Journal of Pure \& Applied Microbiology . 8: 645-650.

., Irawati, N., and Munir, E., 2011,. Isolation and Characterization of Chitinolytic Bacteria Isolated from Soil, and Their Potential to Inhibit Plant Pathogenic Fungi, Microbiology, vol 5, no. 3, hal 144148.

Suryanto, D., Wibowo, R.H., Siregar, E.B.M., Munir, E. 2012. A possibility of chitinolytic bacteria utilization to control basal stem disease caused by Ganoderma boninense in oil palm seedling. Afr. J. Microbiol. Res. 6: 2053-2059. 